\title{
Lying Without Saying Something False? A Cross-Cultural Investigation of the Folk Concept of Lying in Russian and English Speakers
}

\author{
Louisa M. Reins $^{1}$ (D) Alex Wiegmann ${ }^{2}$ (D) $\cdot$ Olga P. Marchenko $^{3} \cdot$ Irina Schumski $^{4}$
}

Accepted: 14 September 2021

(c) The Author(s) 2021

\begin{abstract}
The present study examines cross-cultural differences in people's concept of lying with regard to the question of whether lying requires an agent to say something they believe to be false. While prominent philosophical views maintain that lying entails that a person explicitly expresses a believed-false claim, recent research suggests that people's concept of lying might also include certain kinds of deception that are communicated more indirectly. An important drawback of previous empirical work on this topic is that only few studies have investigated people's concept of lying in non-Western samples. In the present study, we compare people's intuitions about lying with indirect deceptions (i.e., presuppositions, conversational implicatures, and non-verbal actions) in a sample of $N=255$ participants from Russia and $N=300$ participants from the United Kingdom. Our findings show a strong degree of similarity between lie ratings of participants from Russia and the United Kingdom, with both samples holding it possible for agents to lie with deceptive statements and actions that do not involve the agent saying something they believe to be false.
\end{abstract}

\section{Introduction}

The practices of lying and deceiving constitute an important aspect of human communication that can be observed in virtually all societies and cultures. Although there is an extensive body of theoretical and empirical work on questions that concern lying, only few empirical studies have investigated people's

Louisa M. Reins

louisareins@icloud.com

1 Institute of Psychology, Georg August University Göttingen, Göttingen, Germany

2 Institute for Philosophy II, Ruhr University Bochum, Bochum, Germany

3 Insitute of Experimental Psychology, Center of Pre-University Education and Career Guidance, Moscow State University of Psychology and Education, Moscow, Russia

4 Department of Philosophy, Eberhard Karls University Tübingen, Tübingen, Germany 
concept of lying (i.e., how people actually use and understand the term lying) and whether this concept differs across cultures. In the present paper, we aim to address this lacuna by providing a systematic comparison of Russian and English speakers' lie judgments for cases of non-explicit deceptions (i.e., deceptive presuppositions, conversational implicatures, and non-verbal actions).

\section{Theoretical and Empirical Background}

\subsection{Philosophical Definitions of Lying}

Lying is a classic and currently prominent topic in philosophy. According to the predominant view in the philosophical literature, lying entails that speakers assert something they believe to be false. This requirement may be spelled out as follows (cf. Stokke 2018; Viebahn 2019):

$A$ lies to $B$ if and only if there is a proposition $p$ such that

1. A asserts that $p$ to $B$, and

2. $A$ believes that $p$ is false.

This general account has been endorsed by many authors (e.g., Chisholm and Feehan 1977; Adler 1997; Carson 2006, 2010; Sorensen 2007; Fallis 2009; Saul 2012; Stokke 2018). However, the proposals often differ from each other in which accounts of assertion they rely on. In recent years, definitions that rely on a saysbased notion of assertion have become increasingly influential. Let us consider two prominent examples. Stokke (2018), for instance, proposes the following definition:

$A$ lies to $B$ if and only if there is a proposition $p$ such that

1. A says that $p$ to $B$,

2. A proposes to make it common ground that $p$, and

3. $A$ believes that $p$ is false.

According to Saul (2012), on the other hand, a person lies if and only if

1. They say that $p$,

2. They believe $p$ to be false, and

3. They take themselves to be in a warranting context.

For the present purpose, it is important to note that the definitions outlined above require the believed-false proposition to be explicitly communicated. Thus, it is assumed that agents cannot lie by communicating believed-false claims more indirectly, as for instance by means of conversational implicatures (Grice 1989). Consider the following example: 
Dennis is going to Paul's party tonight. He has a long day of work ahead of him before that, but he is very excited and can't wait to get there. Dennis's annoying friend Rebecca comes up to him and starts talking about the party. Dennis is fairly sure that Rebecca won't go unless she thinks he's going, too.

Rebecca: "Are you going to Paul's party?"

Dennis: "I have to work." (cf. Davis 2019; Stokke 2018; Viebahn 2019)

Here, Dennis tricks Rebecca into a false belief by conversationally implicating that he is not going to attend the party. On the level of what is said, however, Dennis's statement is true. Accordingly, the majority of proponents of says- and assertionbased definitions of lying argue that deceptive conversational implicatures do not involve the speaker saying or asserting what they believe to be false, and thus deny that deceptive implicatures amount to lying (e.g., Adler 1997; Dynel 2011; Fallis 2009; Horn 2017; Mahon 2016; Saul 2012; Sorensen 2017; Stokke 2013a, b). The same verdict also holds for other indirect deceptions such as deceptive non-verbal actions (e.g., a divorced person showing a wedding ring they are still wearing as a reply to the question of whether they are married). Stokke (2018) also explicitly denies that a speaker can lie with deceptive presuppositions. In this view, a speaker saying "Jane's brother is nice" while knowing that Jane does not have a brother would not be lying because they merely presupposed that Jane has a brother but did not say it.

\subsection{Empirical Investigations of Lying with Indirect Deceptions}

While there is a strong consensus in the theoretical literature that lying requires a believed-false proposition to be explicitly communicated, empirical findings have challenged this view (see Wiegmann and Meibauer 2019, for an overview of empirical studies on people's concept of lying). In particular, recent findings indicate that people judge certain deceptive conversational implicatures to be cases of lying (e.g., Antomo et al. 2018; Or et al. 2017; Reins and Wiegmann 2021; Wiegmann and Willemsen 2017; but see Weissman and Terkourafi 2019, and Viebahn et al. 2020, for examples of deceptive implicatures that are judged to be merely misleading). In addition, it has been shown that people hold it possible to lie by means of deceptive presuppositions (Reins and Wiegmann 2021; Viebahn et al. 2020) and certain deceptive non-verbal actions (Reins and Wiegmann 2021). Since it is widely agreed that consistency with ordinary people's use and understanding of the term is an important desideratum for any definition of lying (e.g., Arico and Fallis 2013; Carson 2006, 2010; Saul 2012), these findings pose a problem for proponents of says- and assertion-based definitions of lying who hold that deceptive implicatures, presuppositions, and/or non-verbal actions are not said or asserted.

An important drawback of previous studies on lying with indirect deceptions is that they were mostly conducted in English-speaking and Western samples. As pointed out by Henrich et al. (2010) in their seminal paper, findings from these samples cannot readily be taken as universal or representative of populations with different demographic characteristics or cultural backgrounds. In line with this, the few studies having investigated the concept of lying in a cross-cultural manner suggest 
that there might be some variation. Before we turn to our own study that provides a systematic cross-cultural investigation of lying with indirect deceptions in participants from Russia and the United Kingdom, we will give a short overview of the existing cross-cultural research on the concept of lying with a special focus on studies investigating deceptive implicatures.

\subsection{Cross-Cultural Research on the Folk Concept of Lying}

Most cross-cultural research on the folk concept of lying is based on a seminal study by Coleman and Kay (1981), who investigated how lay speakers from the United States represent the English word "lie." Coleman and Kay (1981) assumed that the meaning of the term is represented by a cognitive prototype consisting of three features: objective falsity, subjective falsity (i.e., untruthfulness), and the intention to deceive. Based on their prototype theory, Coleman and Kay (1981) hypothesized that people would represent lying as a graded notion, with deceptive behaviours being more strongly judged to be cases of lying the more prototypical features they entail. In order to test their theory, they constructed a number of deceptive speech acts entailing different combinations of the three features, and had participants evaluate each of the deceptions on a scale from 1 (not a lie, fairly sure) to 7 (lie, fairly sure). Indeed, Coleman and Kay (1981) found that participants' lie ratings were higher the more of the three prototypical features were involved. In addition, their findings showed that subjective falsity was the most constitutive feature of people's prototype of lying, followed by the intention to deceive. Objective falsity, on the other hand, seemed to be of marginal importance only, yielding the findings of Coleman and Kay (1981) consistent with the predominant view in the philosophical literature that lying merely requires what is asserted to be believed to be false.

Coleman and Kay's (1981) study is particularly interesting as it has been followed up by a number of cross-cultural replications. Their original scenarios have been translated into different languages and were tested in Japan (Yoshimura 1995, as cited by Sakaba 2020), Saudi-Arabia (Cole 1996), Ecuador (Hardin 2010), Spain (Eichelberger 2012), and Indonesia (Adha 2020). The replications revealed both similarities and differences to Coleman and Kay's (1981) findings for Englishspeaking participants from the United States. In Saudi-Arabia, the original findings were replicated: participants based their judgments of whether a person lied most strongly on subjective falsity followed by the intention to deceive, while objective falsity played only a marginal role (Cole 1996). In Ecuador and Spain, however, participants relied most strongly on subjective falsity followed by objective falsity, while the intention to deceive seemed to be the least important feature (Eichelberger 2012; Hardin 2010). For Japanese and Indonesian participants, the findings were even more distinct. Here, participants' judgments of whether someone lied were most strongly affected by objective falsity, while the second most important features were the intention to deceive in Indonesia and subjective falsity in Japan. Subjective falsity, then, played only a marginal role in Indonesia, while participants from Japan only marginally relied on an intention to deceive (Adha 2020; Yoshimura 1995, as cited by Sakaba 2020). 
While Coleman and Kay (1981) directly investigated whether lying requires subjective falsity, objective falsity and/or an intention to deceive, they did not directly address the question of whether lying also requires (believed-)false claims to be said. Interestingly, however, one scenario that was included as an example of an intention to deceive in the absence of subjective and objective falsity, in fact, amounted to a conversational implicature. The relevant scenario read:

John and Mary have recently started going together. Valentino is Mary's exboyfriend. One evening John asks Mary, 'Have you seen Valentino this week?' Mary answers, 'Valentino's been sick with mononucleosis for the past two weeks.' Valentino has in fact been sick with mononucleosis for the past two weeks, but it is also the case that Mary had a date with Valentino the night before. Did Mary lie? (Coleman and Kay 1981, p. 31)

Participants' lie ratings for this scenario ranged from 3.19 in Saudi-Arabia, to 3.22 in Indonesia, 3.48 in the United States, 4.12 in Spain, and 4.84 in Ecuador (for an overview, see Eichelberger 2012). ${ }^{1}$ Although all of the ratings are rather close to the scale midpoint, a certain degree of variability can be observed in the different samples.

In a more recent study, Thalmann et al. (2021) compared people's intuitions about lying with deceptive conversational implicatures and non-verbal actions directly in participants from China and Germany. The authors investigated both particularized and generalized conversational implicatures (in the following referred to as GCIs and PCIs), which differ in whether the implicatures arise mainly in dependence of the conversational context vs. certain types of words (Levinson 2000). The case of John and Mary, for example, constitutes a PCI, since the utterance "Valentino's been sick with mononucleosis for the past two weeks" carries the conversational implicature that Mary did not meet with Valentino only in this particular conversational context. The statement "Some of the children failed the test," on the other hand, would be an example of a GCI, as it implicates that not all children failed the test regardless of the context the statement is made in. Overall, the findings of Thalmann et al. (2021) suggest a large degree of similarity between the lie ratings of Chinese and German participants for the cases tested. Both samples mostly judged the deceptive GCIs, but not the deceptive PCIs and deceptive non-verbal actions, to be cases of lying. While this study does show that Chinese and German participants believe it possible to lie by means of GCIs, it is important to note that it does not prove that Chinese and/or German participants never believe it possible to lie by means of PCIs and non-verbal actions. This is because the scenarios used in the study differed not only with respect to how the deceptive content was conveyed (i.e., by means of a GCI, PCI, or non-verbal action), but also in other important respects. Therefore, it is hard to compare the three types of deception directly and it remains conceivable that different findings for PCIs and non-verbal actions would have emerged if matched cases or just a different set of cases in general had been tested.

\footnotetext{
${ }^{1}$ The results for this scenario among Japanese participants (Yoshimura 1995) are not publicly available.
} 
In summary, previous empirical work suggests that people from different cultures might not equally rely on subjective falsity, objective falsity and/or an intention to deceive when making judgments about whether someone lied. With regard to deceptive implicatures, the few existing cross-cultural investigations provide initial evidence that participants from different cultures con- sider certain kinds of indirect deceptions to be cases of lying. In addition, the findings suggest a surprising degree of similarity between different cultures in the classification of deceptive implicatures, although cross-cultural differences might still emerge if a broader range of indirect deceptions were taken into account.

\section{The Present Study}

In the present study, we provide new empirical evidence with regard to the crosscultural comparison of people's lie judgments for cases where agents deceive without explicitly expressing a believed-false proposition. We provide a systematic investigation of four different types of indirect deceptions, namely presuppositions, GCIs, PCIs, and non-verbal actions. Indirect deceptions are a particularly interesting starting point for the investigation of cross-cultural differences in the folk concept of lying, since they do not receive uniformly high lie ratings even within cultures, and thus may be thought to lend themselves to a more pronounced manifestation of cultural differences as compared to prototypical lies.

While participants from the United Kingdom served as a comparison sample, the main focus of our study were participants from Russia, a sample usually highly underrepresented in psychological studies. To our knowledge, there are no empirical investigations that directly address the concept of lying of participants from Russia as of yet, although it seems conceivable that Russians might hold a different concept of lying as compared to participants from the United Kingdom and similar Western countries. Previous research suggests that Russians, as compared to people from the United Kingdom, hold more collectivistic attitudes (Tower et al. 1997), which have been linked to perceiving deceptive behaviours as acceptable when they are used as strategies to avoid conflict and maintain harmony (Seiter et al. 2002). In individualistic cultures, on the other hand, saying the truth is often considered to be one of the most important norms (Hall and Whyte 1979). In addition, it has been suggested that Eastern Europeans engage more in naïve dialectical thinking, which is characterized by the belief that multiple and contradicting truths are possible, whereas Western Europeans seem to be guided more by the law of non-contradiction, according to which a proposition has to be either true or false (e.g., Peng and Nisbett 1999; Spencer-Rodgers et al. 2010; Varnum et al. 2008). In light of these cultural differences, it seems conceivable that people from Russia and the United Kingdom might exhibit different evaluations of lying and deceptive behaviors, both with regard to the acceptability of lying and the kinds of behaviors that count as lying. Hence, the goal of the present study was to investigate potential differences in the concept of lying of participants from Russia and participants from the United Kingdom. 


\section{Method}

\subsection{Participants}

Two subsets of native Russian speaking participants $(N=255)$ were tested in the experiment. The first subset consisted of 152 Russian nationals recruited from the Moscow State University of Psychology and Education. 16 participants of this sample were excluded for failing at least one out of two attention checks, resulting in a final $n=136$ (age: $M=21.84, S D=4.72$; gender: 109 female, 24 male, 3 undisclosed). The second subset consisted of 103 Russian nationals recruited via the UKbased recruitment tool Prolific Academic (Palan and Schitter 2018). 6 participants of this sample were excluded for failing at least one out of two attention checks, resulting in a final $n=97$ (age: $M=32.13, S D=9.55$; gender: 74 female, 21 male, 2 undisclosed). While the first sample primarily consisted of Russian psychology students living in Moscow, the second sample was primarily constituted by Russian adults living in a Western country (e.g., United Kingdom or United States) at the time of data collection. An English version of the experiment had previously been filled out by a sample of $N=300$ native English-speaking participants from the United Kingdom, again recruited via Prolific Academic (age: $M=35.51, S D=12.54$; gender: 177 female, 88 male, 35 undisclosed). Participants in the first sample received course credit in exchange for their participation, while participants in the second and third sample received a compensation of approximately $£ 2$ for taking part in the experiment.

\subsection{Design}

The experiment followed a 4 (type of deception: presupposition vs. GCI vs. PCI vs. action) $\times 4$ (content of scenarios: lottery vs. police vs. marriage vs. texting) mixed design, where the type of deception was manipulated within-subjects, and the content was manipulated partly within and partly between-subjects. Participants were randomly chosen to be presented with two out of the four content domains (i.e., with 8 out of the 16 vignettes that result from crossing the two factors type of deception and content of scenarios). ${ }^{2}$ After reading each of the scenarios, participants were asked whether they thought that each agent had lied and/or misled, and how they would morally evaluate each agent's action.

The misleadingness question was additionally included in order to allow participants to differentiate between lying and misleading; otherwise, participants might have been inclined to classify the cases as lying only to be able to express that they are misleading or deceptive. In addition, the additional assessment of misleadingness allowed us to examine whether any possible differences are specifically bound to judgments of lying or whether they apply to judgments of deceptiveness more

\footnotetext{
${ }^{2}$ Participants were presented with only half of the vignettes to prevent the study from being overly long and tedious.
} 
generally. The morality question, on the other hand, was included so that participants would be able to express their moral evaluation of each of the deceptions, in order to prevent the lying and misleading questions from being inflated by a desire to blame (an effect which has been reported in other judgments related to the moral domain; e.g., Everett et al. 2021). While the design originally resulted in a total of 16 scenarios, 2 scenarios (the PCI in the content domain marriage and the presupposition in the content domain police) were removed from all analyses reported below. The two scenarios had to be excluded because we came to the conclusion that the deceptive statements involved could also be interpreted as being literally false, which rendered the scenarios unsuitable for our purpose of investigating clear cases of indirect deceptions rather than cases of literally false statements (i.e., prototypical lies). ${ }^{3}$

\subsection{Materials and Procedure}

In what follows, all study materials will be described in English (as they were presented to participants in the comparison sample). The Russian translation of the experiment (i.e., the materials as presented to participants in the two Russian samples) can be found in Appendix 1. Following the standard procedure for translating study materials, in a first step, the original materials were translated to Russian by a first native speaker, and then translated back into English and checked for errors or ambiguities by a second native speaker.

\subsubsection{Vignettes}

After reading a brief introduction and explanation of the task, participants were successively presented with the different vignettes, which described situations in which agents deceive other people without explicitly saying anything that they believe to be false. The four vignettes of the content domain lottery, for example, read:

[All versions] Last year, Emma's mother passed away, leaving her a large amount of money behind. With that money, Emma bought herself a nice and big house. Surprisingly, shortly after, Emma also won the lottery, receiving another large amount of money. Today Emma is working in her new house's front yard when her acquaintance Clara, who Emma had not talked to in a while, incidentally walks by on the footway. Emma does not want Clara to know that she bought her house with money she inherited from her mother. That is why, when Clara starts a conversation and asks, 'How did you afford a place like this?' ...

[Presupposition version] Emma answers: 'I admit that I bought the house with money I won in the lottery!'

\footnotetext{
3 For readers familiar with Reins and Wiegmann (2021), we would like to note that the experiment and data presented in the respective paper are not affected by this problem. Reins and Wiegmann (2021) report the results of a later, revised version of the experiment, where the two problematic cases had been replaced.
} 
[GCI version] Emma answers: 'Well, last year I won the lottery and bought this place!'

[PCI version] Emma answers: 'Well, winning the lottery allows people to buy the houses they've always dreamt of!'

[Action version] Emma takes out her smartphone and shows Clara a photograph of herself posing with a giant lottery check in front of her newly purchased house.

[All versions] Clara comes to believe that Emma won the lottery and that she used the money from the lottery win to buy her new house.

The vignettes in the other content domains were structurally equivalent. In the police vignettes, a police officer in training deceives a colleague about whether or not he and his friends failed their final examinations; in the marriage vignettes, a man deceives an old friend about whether or not he is married to a specific woman; and in the texting vignettes, a boy deceives his girlfriend about how many times he recently texted his ex-girlfriend. The English versions of all vignettes tested in the study can be found in Appendix 2.

\subsubsection{Assessed Variables}

After reading each of the vignettes, participants were first asked how they would morally evaluate the agent's behaviour (morality), with the answer options ranging from very bad (1) to very good (7). This question was always presented first, so that participants would be able to act out their desire to blame before evaluating the main dependent variables. Then, participants had to indicate whether the agents in each story misled (misleading), lied (lying), and/or committed a criminal offence (culpability). The latter variable was included only to avoid demand effects where participants feel like they necessarily have to contrast between the former two questions. ${ }^{4}$ The misleading, lying and culpability questions were presented to participants in random order, and in the form of statements to which participants had to indicate their agreement on a scale from completely disagree (1) to completely agree (7). For example, in the content domain Lottery, participants were presented with the following question and statements: 'How would you morally evaluate Emma's behavior?' (morality), 'Emma misled Clara when responding to her question.' (misleading), and 'Emma lied to Clara when responding to her question.' (lie). The exact wording of the dependent variables in Russian and English can be found in Appendix 1 and

\footnotetext{
${ }^{4}$ In particular, we included the culpability question to provide participants with an item to disagree with (since lying to another person in a private context should rarely be considered a criminal offense) for deceptions that might be seen as both cases of lying and misleading. After all, lying is largely considered to be a subtype of misleading, which is why the two concepts in many cases do not come apart. Our concern was that if we didn't include such an additional question, it might have struck participants as odd to repeatedly answer the lying and misleading questions with "yes". This might have led them to think that we (the researchers) must have wanted them to somehow differentiate between the two questions, which then could have been a possible source for a demand bias.
} 
Table 1 Sample comparison of participants' lie ratings

\begin{tabular}{lllrrr}
\hline Comparison & Predictor & numDF & denDF & F-value & p-value \\
\hline 1 & (Intercept) & 1 & 1398 & 5236.73 & $<0.001^{*}$ \\
Russia I vs. Russia II & Category & 3 & 1398 & 75.61 & $<0.001^{*}$ \\
& Sample & 1 & 231 & 6.29 & $=0.013^{*}$ \\
& Category:sample & 3 & 1398 & 2.45 & $=0.063$ \\
2 & (Intercept) & 1 & 2611 & $11,075.26$ & $<0.001^{*}$ \\
Russia I vs. UK & Category & 3 & 2611 & 133.48 & $<0.001^{*}$ \\
& Sample & 1 & 434 & 9.13 & $=0.003^{*}$ \\
3 & Category:sample & 3 & 2611 & 2.56 & $=0.054$ \\
Russia II vs. UK & (Intercept) & 1 & 2393 & $12,697.80$ & $<0.001^{*}$ \\
& Category & 3 & 2393 & 122.49 & $<0.001^{*}$ \\
& Sample & 1 & 395 & 0.14 & $=0.708$ \\
& Category:sample & 3 & 2393 & 0.85 & $=0.466$ \\
\hline
\end{tabular}

Relevant parameters are printed in bold. * indicates $\mathrm{p}<0.05$. Reported $\mathrm{p}$-values are not adjusted for multiple comparisons (adjusting them would not change the relevant inferences, adjusted alpha-level: $\alpha=0.05 / 3=0.017$ ). Russia $\mathrm{I}=$ Russian nationals living in Moscow, Russia $\mathrm{II}=$ Russian nationals living in a Western country, United Kingdom = native English-speaking participants from the United Kingdom

2, respectively. The term "to lie" in the main dependent variable was translated as "солгать" (solgát') in the Russian version of the experiment.

\section{Results}

\subsection{Lie Ratings}

As a first step, in order to examine whether participants' lie ratings from the two Russian samples could be entered into our analyses as one sample, we tested for differences between participants' lie ratings in the two samples. In a multilevel model taking participants into account as a random factor, we predicted participants' lie ratings from sample (Russian participants living in Moscow (=Russia I) vs. Russian participants living in a Western country (= Russia II)), category of deception (presupposition vs. GCI vs. PCI vs. non-verbal action), and the interaction of the two factors. This analysis suggested that participants' lie ratings in the two Russian samples were significantly different from each other (see Table 1, comparison 1). Thus, we decided to examine the two samples separately.

Next, we assessed whether participants' lie ratings in each of the two Russian samples were significantly different from participants' lie ratings in the UK comparison sample, using the same approach as described above. The analyses revealed that participants' lie ratings in the sample of Russian participants living in Moscow significantly differed from participants' lie ratings in the UK comparison sample, whereas participants' lie ratings in the sample of Russians living in a Western 


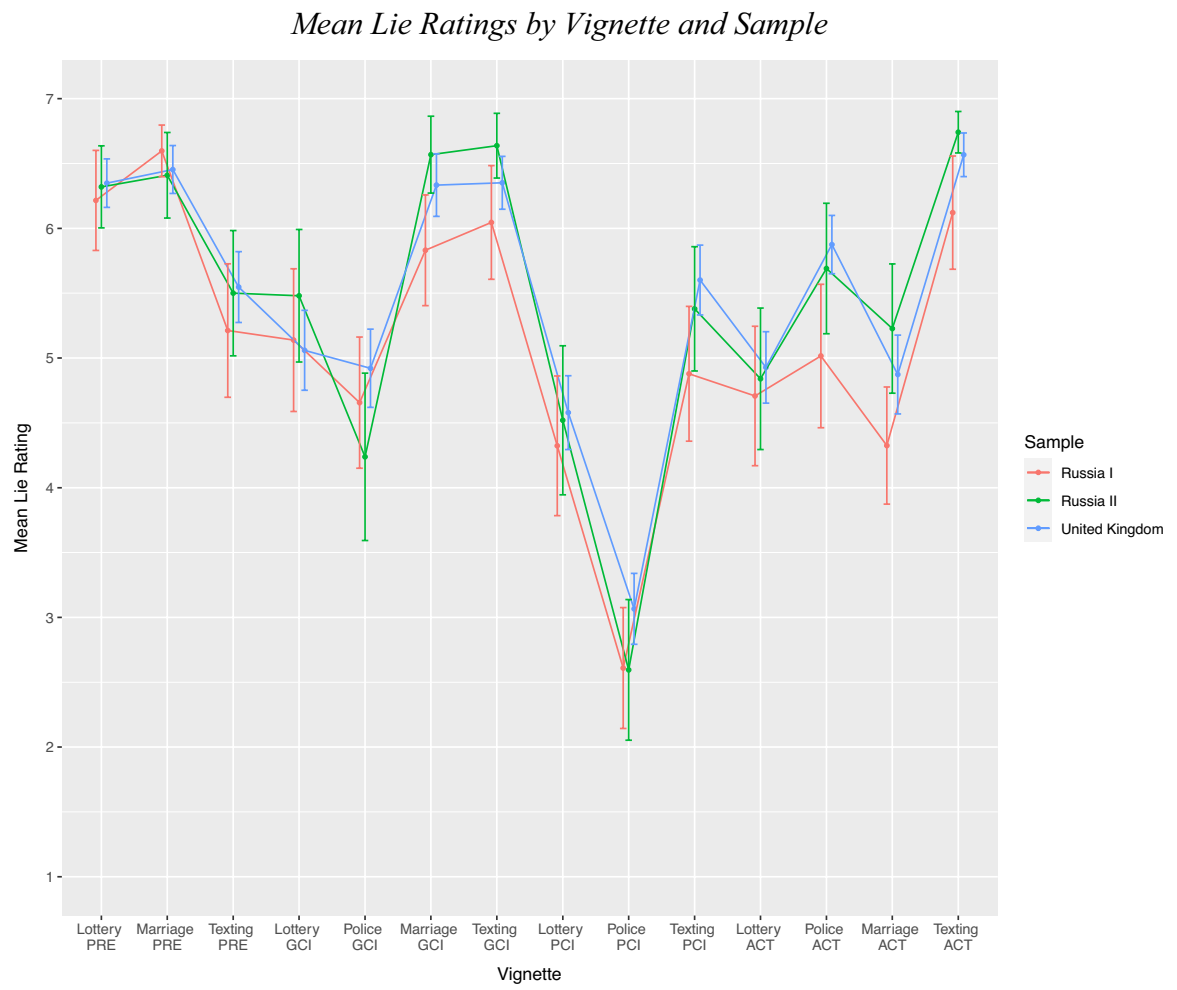

Fig. 1 Mean Lie ratings by Vignette and sample. Note Lie ratings were measured on a scale from 1 to 7 , with " 1 " indicating strong disagreement with the claim that each agent lied and "7" indicating strong agreement with the claim. Error bars indicate $95 \%$ confidence intervals around means. Russia I=Russian nationals living in Moscow, Russia II = Russian nationals living in a Western country, United Kingdom = native English-speaking participants from the United Kingdom. PRE = presupposition, GCI = generalized conversational implicature, $\mathrm{PCI}=$ particularized conversational implicature, ACT $=$ non-verbal action

country did not significantly differ from participants' lie ratings in the UK comparison sample (see Table 1, comparison 2 and 3).

Figures 1 and 2 show participants' mean lie ratings in each of the samples as a function of vignette and type of deception (i.e., presupposition, GCI, PCI, non-verbal action), respectively. As we can see, participants' lie ratings from all three samples follow a highly similar pattern, although lie ratings in the sample of Russian participants living in Moscow are somewhat lower than lie ratings in the remaining two samples. Post-hoc tests comparing the three samples' lie ratings averaged over each type of deception (i.e., as depicted in Fig. 2) revealed that the only statistically significant difference between samples emerged for non-verbal actions, where lie ratings were significantly lower in the sample of Russian participants living in Moscow as compared to each of the two other samples (both $\mathrm{p}<0.004$, which amounts to the alpha-level adjusted for the number of comparisons performed $(=0.05 / 12)$ ). The effect size (Cohen's $d$ ) of the 


\section{Mean Lie Ratings by Type of Deception and Sample (Collapsed across Vignettes)}

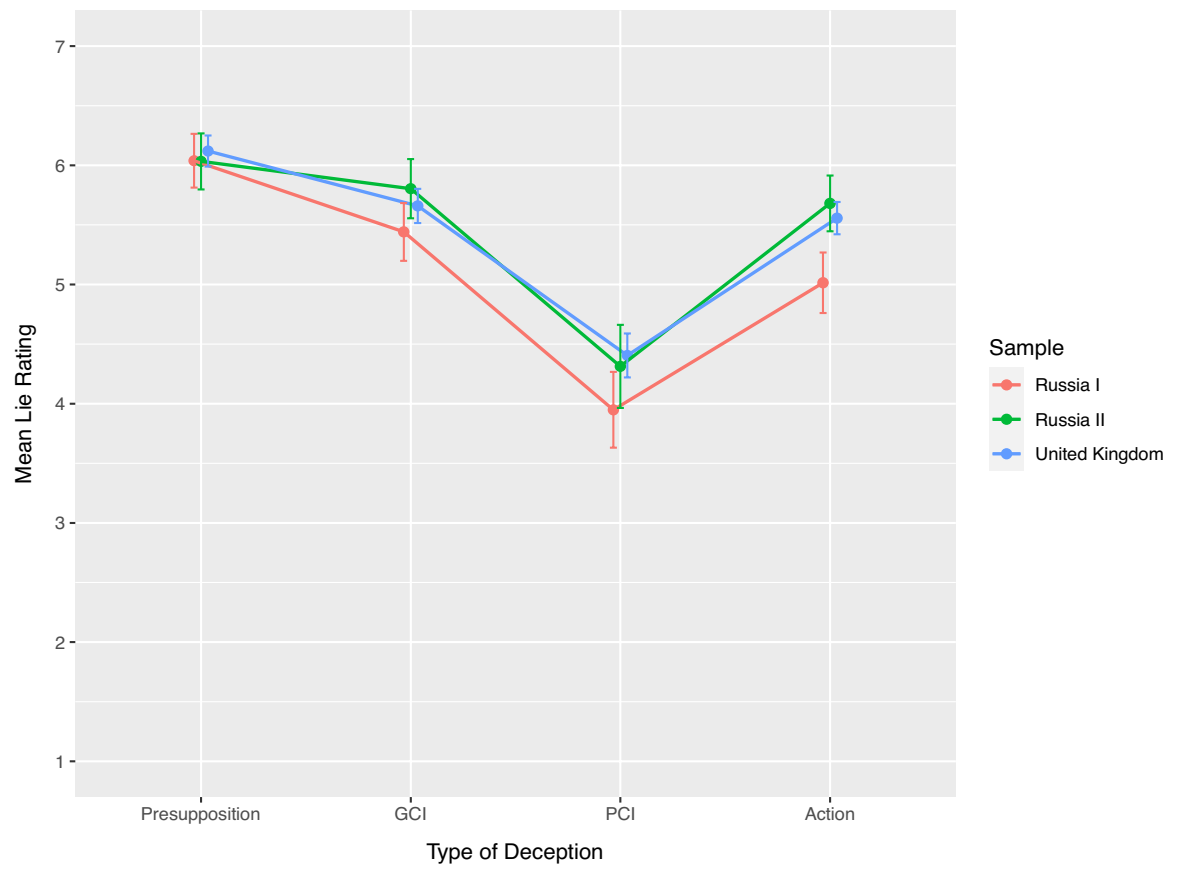

Fig. 2 Mean Lie ratings by type of deception and sample (collapsed across vignettes). Note Lie ratings were measured on a scale from 1 to 7 , with " 1 " indicating strong disagreement with the claim that each agent lied and " 7 " indicating strong agreement with the claim. Error bars indicate $95 \%$ confidence intervals around means. Russia I= Russian nationals living in Moscow, Russia II = Russian nationals living in a Western country, United Kingdom = native English-speaking participants from the United Kingdom. $\mathrm{GCI}=$ generalized conversational implicature, $\mathrm{PCI}=$ particularized conversational implicature

differences between lie ratings from Russian participants living in Moscow and Russian participants living in a Western country was trivial for presuppositions $(d=0$ [ $-0.26 ; 0.25])$, while it was small for GCIs $(d=-0.21[-0.45 ; 0.02])$, PCIs $(d=-0.21[-0.47 ; 0.05])$ and non-verbal actions $(d=-0.39[-0.63$; - 0.16]). Similarly, the effect size of the differences between lie ratings from Russian participants living in Moscow and participants from the UK was trivial for presuppositions $(d=-0.06[-0.25 ; 0.14])$ and GCIs $(d=-0.13[-0.31$; $0.05])$, while it was small for PCIs $(d=-0.27[-0.48 ; 0.07])$ and non-verbal actions $(d=-0.33[-0.51 ;-0.15])$. Despite these small differences, our findings indicate that participants in all samples predominantly judged the deceptive presuppositions, GCIs and non-verbal actions included in our study to be cases of lying. For PCIs, lie ratings were somewhat lower in all samples, although at least one of the cases (i.e., the PCI in the content domain Texting) was still judged to be a case of lying by both Russian samples and the UK-based sample. 
Table 2 Sample comparison of participants' misleading ratings

\begin{tabular}{lllrrl}
\hline Comparison & Predictor & numDF & denDF & F-value & p-value \\
\hline 1 & (Intercept) & 1 & 1398 & 6075.80 & $<0.001^{*}$ \\
Russia I vs. Russia II & Category & 3 & 1398 & 23.37 & $<0.001^{*}$ \\
& Sample & 1 & 231 & 0.82 & $=0.366$ \\
& Category:sample & 3 & 1398 & 0.91 & $=0.437$ \\
2 & (Intercept) & 1 & 2611 & $17,510.46$ & $<0.001^{*}$ \\
Russia I vs. UK & Category & 3 & 2611 & 65.32 & $<0.001^{*}$ \\
& Sample & 1 & 434 & 25.15 & $<0.001^{*}$ \\
& Category:sample & 3 & 2611 & 1.68 & $=0.170$ \\
3 & (Intercept) & 1 & 2393 & $22,197.43$ & $<0.001^{*}$ \\
Russia II vs. UK & Category & 3 & 2393 & 82.64 & $<0.001^{*}$ \\
& Sample & 1 & 395 & 14.42 & $<0.001^{*}$ \\
& Category:sample & 3 & 2393 & 0.48 & $=0.694$ \\
\hline
\end{tabular}

Relevant parameters are printed in bold. * indicates $\mathrm{p}<0.05$. Reported $\mathrm{p}$-values are not adjusted for multiple comparisons (adjusting them would not change the relevant inferences, adjusted alpha-level: $\alpha=0.05 / 3=0.017$ ). Russia $\mathrm{I}=$ Russian nationals living in Moscow, Russia $\mathrm{II}=$ Russian nationals living in a Western country, United Kingdom = native English-speaking participants from the United Kingdom

\subsection{Misleadingness Ratings}

In order to assess whether the pattern observed above is specific to judgments of lying or whether it applies to judgments of deceptiveness in general, we also assessed participants' ratings of whether each deception constituted a case of misleading. Using the same multilevel approach as described in Sect. 5.1, we compared participants' misleadingness ratings in all three samples (i.e., predicting participants' misleadingness ratings by sample, type of deception, and their interaction, while taking participants into account as a random factor). This time, participants' misleading ratings did not significantly differ in the two Russian samples (see Table 2, comparison 1), while the ratings in both Russian samples were significantly different from participants' ratings in the UK sample (see Table 2, comparison 2 and 3).

Figure 3 shows participants' mean misleadingness ratings in each of the samples as a function of type of deception (i.e., presupposition, GCI, PCI, non-verbal action). Again, participants' misleadingness ratings from all three samples follow a highly similar pattern, although misleadingness ratings in the two Russian samples are somewhat lower than misleadingness ratings in the UK sample. Furthermore, the figure shows that all of the tested deceptions were predominantly judged to be cases of misleading in all samples, although PCIs received slightly lower misleadingness ratings than the remaining deceptions. 


\section{Mean Misleadingness Ratings by Type of Deception and Sample (Collapsed across Vignettes)}

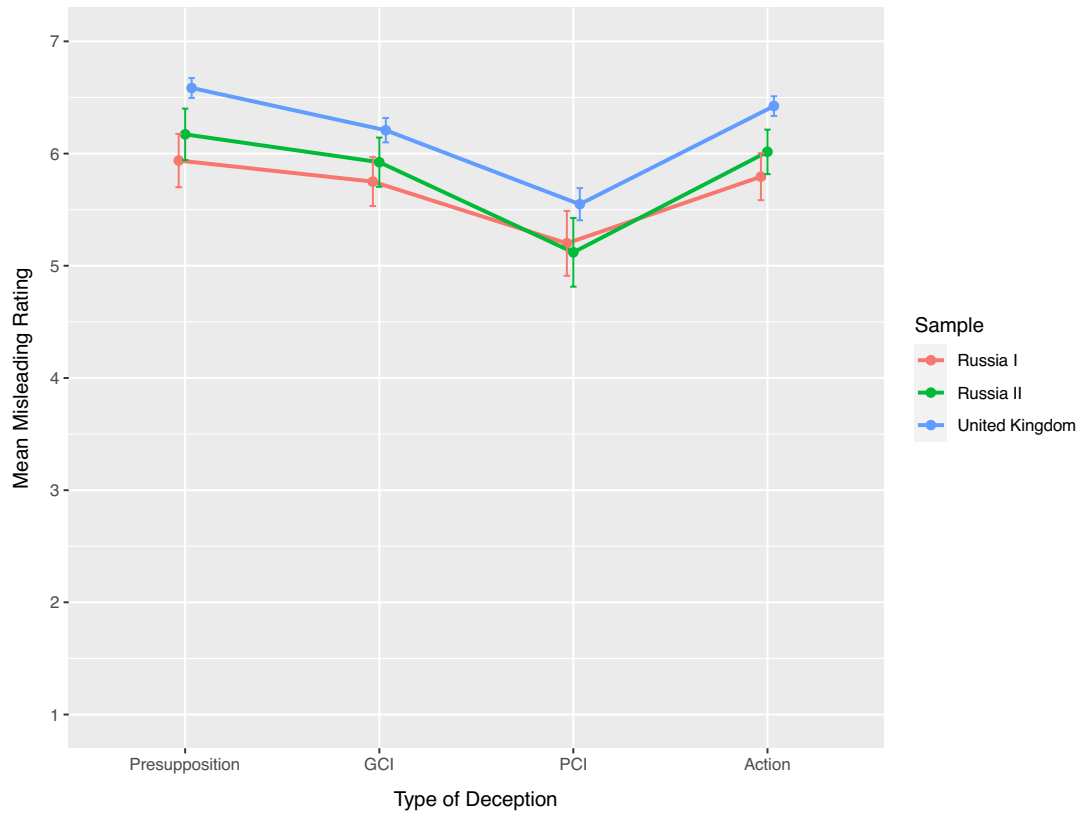

Fig. 3 Mean misleadingness ratings by type of deception and sample (collapsed across vignettes). Note Misleadingness ratings were measured on a scale from 1 to 7 , with "1" indicating strong disagreement with the claim that each agent misled and "7" indicating strong agreement with the claim. Error bars indicate 95\% confidence intervals around means. Russia $I=$ Russian nationals living in Moscow, Russia II = Russian nationals living in a Western country, United Kingdom=native English-speaking participants from the United Kingdom. GCI=generalized conversational implicature, $\mathrm{PCI}=$ particularized conversational implicature

Table 3 Sample comparison of participants' morality ratings

\begin{tabular}{lllrrl}
\hline Comparison & Predictor & numDF & denDF & F-value & p-value \\
\hline 1 & (Intercept) & 1 & 1398 & 2516.37 & $<0.001^{*}$ \\
Russia I vs. Russia II & Category & 3 & 1398 & 43.16 & $<0.001^{*}$ \\
& Sample & 1 & 231 & 0.03 & $=0.864$ \\
& Category:sample & 3 & 1398 & 0.96 & $=0.409$ \\
2 & (Intercept) & 1 & 2611 & 4443.08 & $<0.001^{*}$ \\
Russia I vs. UK & Category & 3 & 2611 & 63.56 & $<0.001^{*}$ \\
& Sample & 1 & 434 & 15.19 & $<0.001^{*}$ \\
& Category:sample & 3 & 2611 & 3.33 & $=0.019^{*}$ \\
3 & (Intercept) & 1 & 2393 & 4068.19 & $<0.001^{*}$ \\
Russia II vs. UK & Category & 3 & 2393 & 54.42 & $<0.001^{*}$ \\
& Sample & 1 & 395 & 13.67 & $<0.001^{*}$ \\
& Category:sample & 3 & 2393 & 1.32 & $=0.265$ \\
\hline
\end{tabular}

Relevant parameters are printed in bold. * indicates $\mathrm{p}<0.05$. Reported $\mathrm{p}$-values are not adjusted for multiple comparisons (adjusting them would not change the relevant inferences, adjusted alpha-level: $\alpha=0.05 / 3=0.017$ ). Russia $\mathrm{I}=$ Russian nationals living in Moscow, Russia $\mathrm{II}=$ Russian nationals living in a Western country, United Kingdom = native English-speaking participants from the United Kingdom 


\section{Mean Morality Ratings by Type of Deception and Sample (Collapsed across Vignettes)}

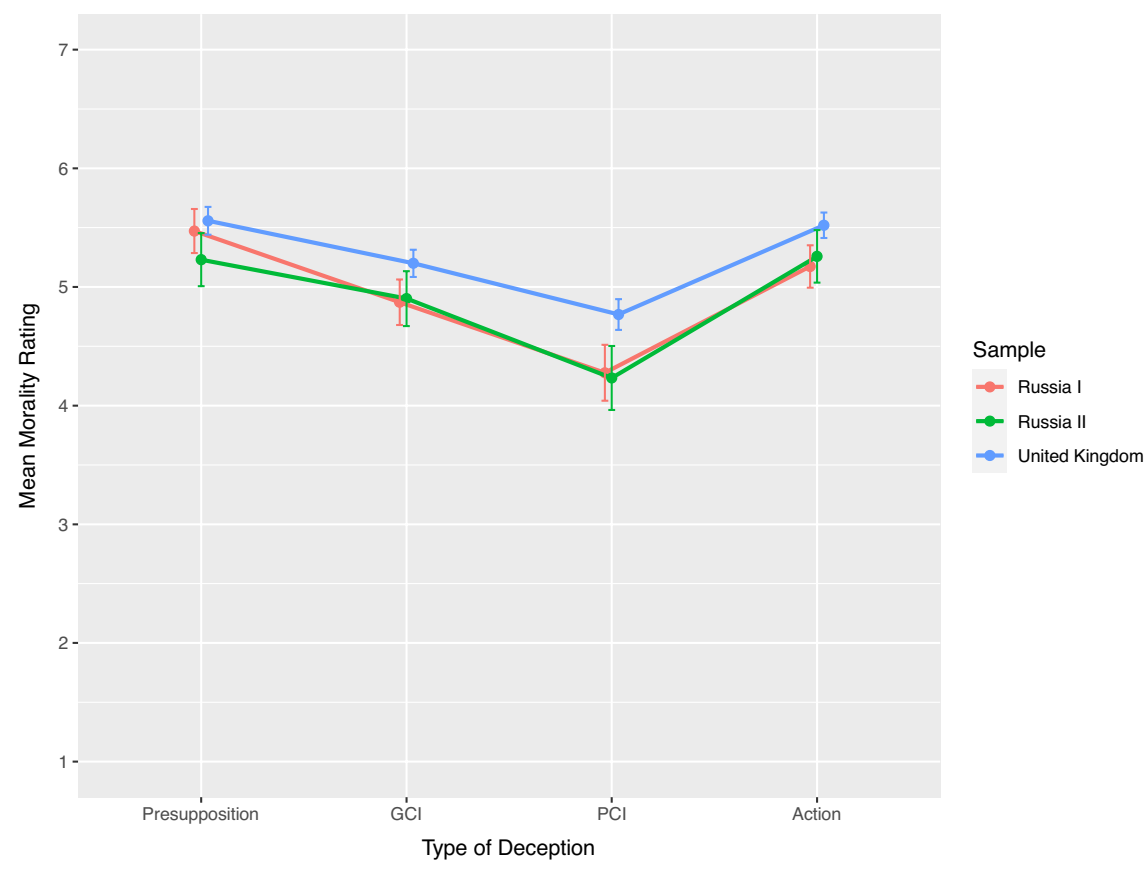

Fig. 4 Mean morality ratings by type of deception and sample (collapsed across vignettes). Note Morality ratings were measured on a scale from 1 to 7 . For this figure, participants' morality ratings were reversed, so that " 1 " indicates that an agent's behaviour was judged to be "very good" and "7" indicates that it was judged to be "very bad". Error bars indicate $95 \%$ confidence intervals around means. Russia $\mathrm{I}=$ Russian nationals living in Moscow, Russia II = Russian nationals living in a Western country, United Kingdom = native English-speaking participants from the United Kingdom. GCI= generalized conversational implicature, $\mathrm{PCI}=$ particularized conversational implicature

\subsection{Morality Ratings}

Finally, we examined participants' moral evaluations of each of the deceptions tested in the study. Again, participants' morality ratings in the three samples were compared using a multilevel approach (i.e., predicting participants' morality ratings by sample, type of deception, and their interaction, while taking participants into account as a random factor). The analyses revealed that participants' morality ratings did not significantly differ in the two Russian samples (see Table 3, comparison 1 ), while the ratings in both Russian samples were significantly different from participants' ratings in the sample from the UK (see Table 3, comparison 2 and 3).

Figure 4 shows participants' mean morality ratings in each of the samples as a function of type of deception (presupposition, GCI, PCI, non-verbal action). Higher values indicate that an agent's behaviour was judged to be "morally bad", while lower values indicate that an agent's behaviour was judged to be "morally good" (i.e., participants' morality ratings are reversed in the figure). Again, moral 
reprehensibility ratings from all three samples follow a highly similar pattern, although participants from the two Russian samples overall judged the deceptions to be less morally reprehensible as compared to participants from the UK, in particular with regard to deceptive PCIs. Furthermore, we can see that all samples predominantly judged the deceptions investigated in our study to be morally bad, although the PCIs investigated were overall seen as somewhat less morally reprehensible than the remaining types of deception.

\section{Discussion}

In the present paper, we investigated cross-cultural differences in people's concept of lying with regard to deceptive statements that are communicated indirectly, rather than being explicitly said by an agent. While says-based definitions of lying hold that such deceptions do not amount to lying, previous findings have shown that people from Western cultures sometimes hold it possible to lie with such. In the present study, we provide a first systematic empirical investigation of lying with indirectly communicated deceptions (i.e., deceptive presuppositions, deceptive conversational implicatures, and deceptive non-verbal actions) comparing Russian participants $(N=255)$ with a sample from the United Kingdom $(N=300)$.

\subsection{Discussion of Results}

\subsubsection{Cultural Differences}

We found that Russian participants living in Moscow gave overall lower lie ratings for indirect deceptions as compared to participants from the United Kingdom, and that Russian participants in general judged the tested deceptions to be less morally reprehensible as compared to participants from the United Kingdom. These differences might possibly be linked to previous findings according to which Eastern and Western Europeans differ in their endorsement of naïve dialectical thinking and collectivistic vs. individualistic values (e.g., Tower et al. 1997; Varnum et al. 2008; see Sect. 3). It is important to note, however, that Russian participants from Moscow did not only judge the deceptions to be less a case of lying, but also to be less misleading. Therefore, the differences observed might result from a different perception of the tested cases' deceptiveness, rather than a different underlying conceptualization of the term lying. Interestingly, we also observed that the two Russian samples slightly differed in their lie judgments, as the judgments from Russian participants living in a Western country resembled the lie judgments of participants from the United Kingdom more strongly than lie judgments from Russian participants living in Moscow. A possible explanation for this pattern might be that Russians living in a Western country have adopted the Western view through processes of acculturation. However, this explanation would probably also predict participants' misleading and 
morality ratings to show an effect of acculturation, for which we did not find a difference between the two Russian samples.

\subsubsection{Cultural Similarities}

It is important to note that all of the differences described above were rather small in magnitude and did not change the overall evaluation of the investigated deceptions as cases of lying. In particular, the lie ratings from all three samples still followed a highly similar pattern, with participants from Russia and the United Kingdom believing it possible to lie with deceptive presuppositions, generalized conversational implicatures, and non-verbal actions, as well as some kinds of particularized conversational implicatures. Thus, our findings suggest a strong degree of similarity in the classification of indirectly communicated deceptions between people from Russia and the United Kingdom. Although previous studies have identified a number of cross-cultural differences with regard to the questions of whether lying requires objective falsity and an intention to deceive (e.g., Adha 2020; Coleman and Kay 1981; Eichelberger 2012; Hardin 2010; Yoshimura 1995, as cited by Sakaba 2020), our findings are in line with the few existing studies on lying with indirectly communicated deceptions that did not report any substantial cross-cultural differences in the evaluation of such cases (cf. Eichelberger 2012; Thalmann et al. 2021).

\subsubsection{Implications for Says- and Assertion-Based Definitions of Lying}

Our findings indicate that both people from Russia and the United Kingdom believe that one can lie with certain types of deception that-according to proponents of says- and assertion-based definitions of lying-do not involve a false proposition being said, stated or asserted. In particular, there is a strong consensus that conversational implicatures are not entailed by what is said (e.g., Mahon 2016; Saul 2012; Stokke 2013b, 2017) and, accordingly, that deceptive implicatures do not constitute cases of lying (e.g., Adler 1997; Dynel 2011; Fallis 2009; Horn 2017; Mahon 2016; Saul 2012; Sorensen 2017; Stokke 2013a, b). The same verdict holds for deceptive non-verbal actions, while Stokke (2018) also explicitly denies that presuppositions are asserted and can serve as lies. Given that it is one of the most important desiderata for philosophical definitions of lying to capture people's intuitions about the concept (e.g., Arico and Fallis 2013; Carson 2006, 2010; Saul 2012), our findings pose a problem for narrow says- and assertion-based definitions of lying. For a more detailed discussion of the implications of the present and related findings for different definitions of lying, as well as a proposal of an alternative definition of lying based on commitment, see Reins and Wiegmann (2021).

\subsection{Limitations and Avenues for Future Research}

One might critically note that our samples differed not only with regard to the participants' cultural background, but also with regard to several other demographic 
characteristics. While the first Russian sample predominantly consisted of students (mean age $=21.84$ ), our sample from the United Kingdom was a mixed sample (mean age $=35.51$ ). The second sample of Russian participants, on the other hand, resembled our UK sample in demographic characteristics (mean age $=32.13$ ), but consisted of Russians who did not live in Russia at the time of data collection. While this composition of our samples allowed us to gain first insights into a possible role of acculturation, it would also be interesting to examine whether similar results would be obtained if a mixed sample of Russian participants who live in Russia or a sample of students from the United Kingdom were additionally investigated. Furthermore, it is to be noted that the Russian language contains a number of different terms with a comparable meaning to the English words "lie" and "lying" (e.g., lozh', obmán, neprávda, lgat', vrat'; cf. Shatilova et al. 2018; Wierzbicka 2002). While we translated the term "to lie" as "солгать" (solgát') in the present study, future research might examine if and how the concepts associated with these different terms diverge from each other.

Further interesting avenues for future research include an examination of whether people really perceived the verbal deceptions investigated in our study (i.e., the deceptive presuppositions and conversational implicatures) to not involve any literally false statements (i.e., whether people would agree that nothing false has been said in each of the cases). Based on our findings, we cannot exclude the possibility that participants hold a different concept of what is said than assumed in the philosophical and linguistic literature. In addition, if we assume that the small differences we observed between our samples replicate, it would also be interesting to examine factors potentially underlying these findings, for instance by assessing whether differences in intuitions about lying correspond to certain cultural factors such as differences in naïve dialectical thinking or the endorsement of collectivistic vs. individualistic values. Finally, future studies should be employed to investigate deceptive presuppositions, conversational implicatures, and non-verbal actions in a yet larger sample of different languages and cultures, in order to examine whether people's evaluation of such indirectly communicated deceptions as lies is truly universal or bound to specific cultures such as Russia and the United Kingdom. ${ }^{5}$

\footnotetext{
5 We thank two anonymous reviewers for raising the points discussed in this last paragraph.
} 


\title{
Appendix 1: Russian Version of All Vignettes Tested in the Study
}

\author{
МАТЕРИАЛ А: ЛОТЕРЕЯ \\ Сценарии
}
[Для всех версий]
В прошлом году мать Эммы умерла, оставив ей после себя большую сумму денег. На эти деньги Эмма купила себе большой красивый дом. Удивительно, но вскоре после этого Эмма также выиграла в лотерею, получив еще одну большую сумму денег. Сегодня Эмма работает на переднем дворе своего нового дома, когда ее знакомая Клара, с которой Эмма давно не общалась, случайно проходит мимо ее дома. Эмма не хочет, чтобы Клара знала, что она купила свой дом на деньги, унаследованные от матери. Поэтому, когда Клара начинает разговор и спрашивает: «Как ты смогла позволить себе такой дом?»- Эмма...

$\begin{array}{llll}\text { [Предположение] } & {[\mathrm{GCI}]} & {[\mathrm{PCI}]} & \text { [Действие] } \\ \text {...отвечает: «Должна } & \text {. .отвечает: «Ну, в } & \text {. .отвечает: «Ну, } & \text {..доостает смартфон } \\ \text { признать, что я } & \text { прошлом году я } & \text { выигрыш в лотерею } & \text { и показывает Кларе } \\ \text { купила этот дом на } & \text { выиграла в лотерею } & \text { позволяет людям } & \text { фотографию, на } \\ \text { деньги, которые } & \text { и купила этот дом!» } & \text { покупать дома, о } & \text { которой Эмма } \\ \text { выиграла в лотерею } & & \text { которых они всегда } & \text { позирует с огромным } \\ \text { в прошлом году!» } & \text { мечтали!» } & \text { лотерейным чеком на } \\ & & & \text { фоне новокупленного } \\ & & \end{array}$

[Для всех версий]

Клара поверила, что Эмма выиграла в лотерею и использовала выигранные деньги, чтобы купить свой новый дом.

\section{Зависимые переменные}

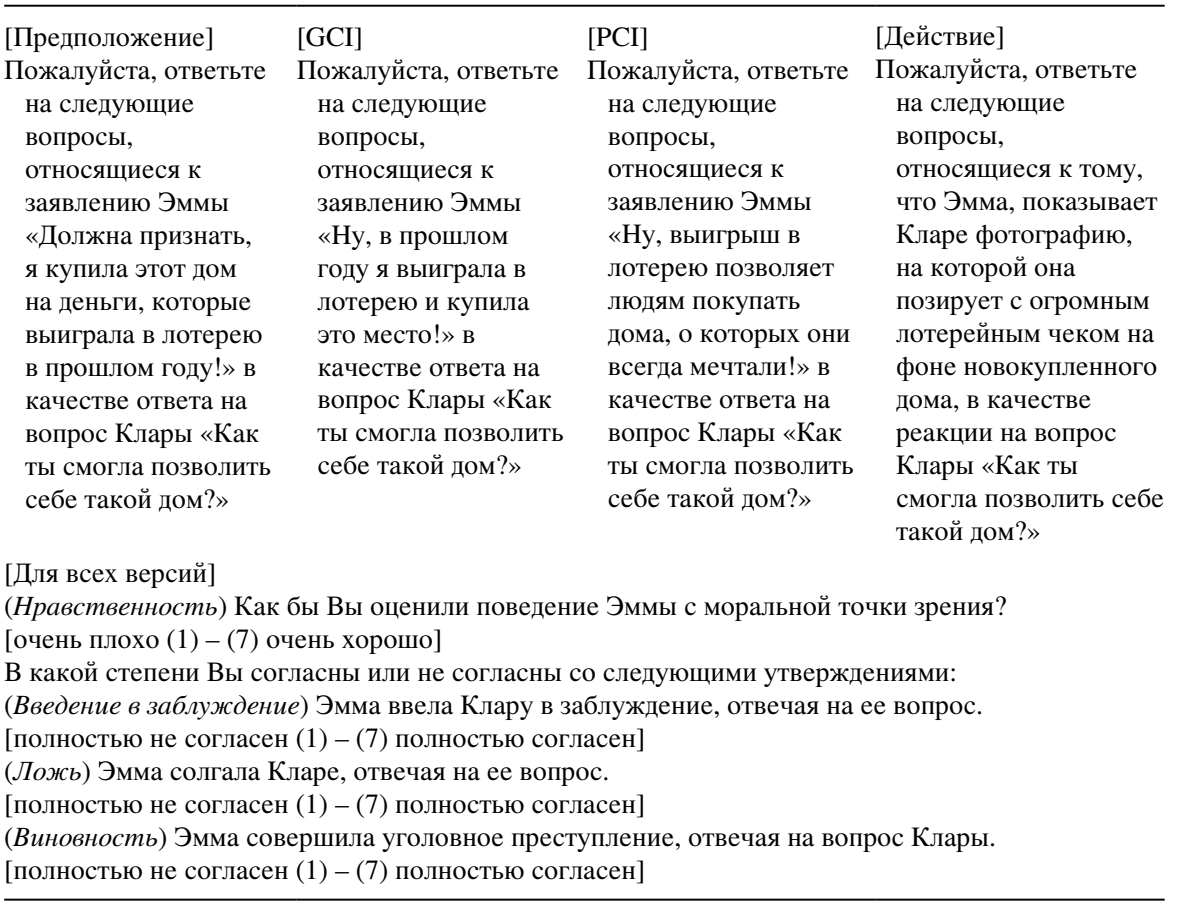




\section{МАТЕРИАЛ В: ПОЛИЦИЯ}

\section{Сценарии}

[Для всех версий]

Питер, Джон и Карл являются учащимися в полицейской академии, готовящимися стать полицейскими. Сегодня у них были выпускные экзамены. К сожалению, все трое провалили экзамены. Выходя из экзаменационного центра, они сталкиваются с другим учащимся академии Шоном. Трое друзей не хотят, чтобы Шон знал, что все они провалили экзамены, поэтому, когда Шон спрашивает: «Ну что, все ли из вас завалили тест сегодня?» - Питер...

$\begin{array}{llll}\text { [Предположение] } & {[\mathrm{GCI}]} & {[\mathrm{PCI}]} & \text { [Действие] } \\ \text { [case exluded }] & \text {..отвечает: «Ну, } & \text {. } о \text { отвечает: «Люди, } & \text {. .запускает руку в } \\ & \text { некоторые из нас } & \text { которые тебе } & \text { карман, достает оттуда } \\ \text { провалили тест». } & \text { не нравятся, } & \text { полицейский жетон, } \\ & \text { необязательно } & \text { который он незаконно } \\ & \text { являются } & \text { не вернул после } \\ & \text { неудачниками». } & \text { провала на экзамене, и }\end{array}$

[Для всех версий]

Шон поверил, что не все из троицы провалили экзамены.

\section{Зависимые переменные}

\begin{tabular}{|c|c|c|c|}
\hline Предположение] & [GCI $]$ & {$[\mathrm{PCI}]$} & [Действие] \\
\hline case exluded] & $\begin{array}{l}\text { Пожалуйста, ответьте } \\
\text { на следующие } \\
\text { вопросы, относящиеся } \\
\text { к заявлению Питера } \\
\text { «Ну, некоторые из } \\
\text { нас провалили тест» } \\
\text { в качестве ответа на } \\
\text { вопрос Шона «Ну что, } \\
\text { все ли из вас завалили } \\
\text { тест сегодня?» }\end{array}$ & $\begin{array}{l}\text { Пожалуйста, ответьте } \\
\text { на следующие } \\
\text { вопросы, } \\
\text { относящиеся к } \\
\text { заявлению Питера } \\
\text { «Люди, которые } \\
\text { тебе не нравятся, } \\
\text { необязательно } \\
\text { являются } \\
\text { неудачниками» в } \\
\text { качестве ответа на } \\
\text { вопрос Шона «Ну что, } \\
\text { все ли из вас завалили } \\
\text { тест сегодня?» }\end{array}$ & $\begin{array}{l}\text { Пожалуйста, ответьте на } \\
\text { следующие вопросы, } \\
\text { относящиеся к тому, } \\
\text { что Питер показывает } \\
\text { полицейский жетон, } \\
\text { который он незаконно } \\
\text { не вернул после } \\
\text { провала на экзамене, } \\
\text { в качестве реакции на } \\
\text { вопрос Шона «Ну что, } \\
\text { все ли из вас завалили } \\
\text { тест сегодня?» }\end{array}$ \\
\hline \multicolumn{4}{|c|}{$\begin{array}{l}\text { [Для всех версий] } \\
\text { (Нравственность) Как бы Вы оценили поведение Питера с моральной точки зрения? } \\
\text { [очень плохо (1) - (7) очень хорошо] } \\
\text { В какой степени Вы согласны или не согласны со следующими утверждениями: } \\
\text { (Введение в заблуждение) Питер ввел Шона в заблуждение, отвечая на его вопрос. } \\
\text { [полностью не согласен (1) - (7) полностью согласен] } \\
\text { (Ложь) Питер солгал Шону, отвечая на его вопрос. } \\
\text { [полностью не согласен (1) - (7) полностью согласен] } \\
\text { (Виновность) Питер совершил уголовное преступление, отвечая на вопрос Шона. } \\
\text { [полностью не согласен (1) - (7) полностью согласен] }\end{array}$} \\
\hline
\end{tabular}




\section{МАТЕРИАЛ С: БРАК \\ Сценарии}

[Для всех версий]

На встрече выпускников Фрэнк встречает своего давнего одноклассника Гарри. Они начинают говорить о своих отношениях еще в колледже и о семьях, которые у них есть сейчас. Дело в том, что Фрэнк расстался с Дженни, которая была его девушкой в колледже, всего через несколько лет после их выпуска. В прошлом году он женился на другой женщине по имени Джойс, и он знает, что его бывшая девушка Дженни также вышла замуж за другого мужчину в прошлом году. Однако Фрэнк не хочет, чтобы Гарри знал, что у них с Дженни ничего не получилось. Поэтому, когда Гарри спрашивает: «Ну что, как у вас с Дженни все сложилось?» -Фрэнк...

[Предположение]

...отвечает: «Наша с Дженни свадьба была прекрасна!»
[GCI]

...отвечает: «Я и Дженни поженились в прошлом году!»
[PCI] [Действие]

[case exluded] ...широко улыбается, поднимает руку и показывает Гарри свое свадебное кольцо с выгравированной на нем буквой «Д».

[Для всех версий]

Гарри поверил, что Фрэнк женился на Дженни.

\section{Зависимые переменные}

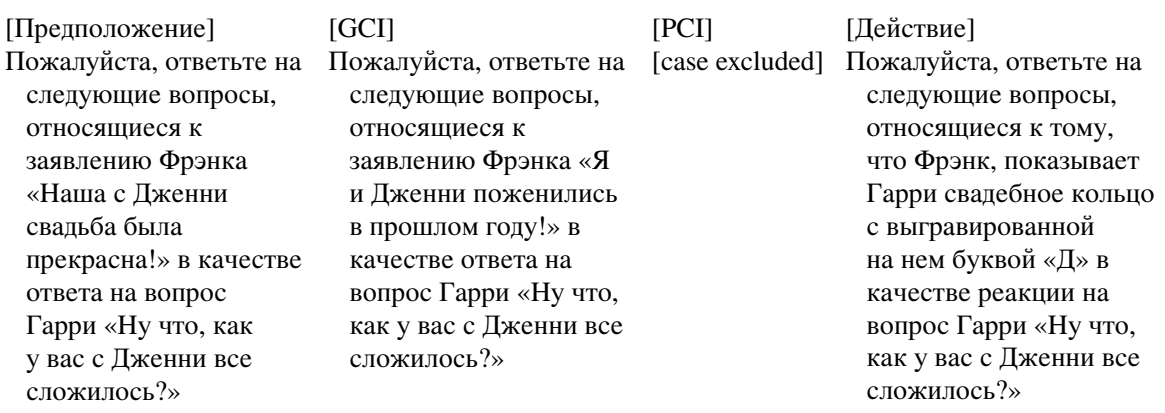

[Для всех версий]

(Нравственность) Как бы Вы оценили поведение Фрэнка с моральной точки зрения? [очень плохо (1) - (7) очень хорошо]

В какой степени Вы согласны или не согласны со следующими утверждениями:

(Введение в заблуждение) Фрэнк ввел Гарри в заблуждение, отвечая на его вопрос. [полностью не согласен (1) - (7) полностью согласен] (Ложь) Фрэнк солгал Гарри, отвечая на его вопрос. [полностью не согласен (1) - (7) полностью согласен] (Виновность) Фрэнк совершил уголовное преступление, отвечая на вопрос Гарри. [полностью не согласен (1) - (7) полностью согласен] 


\section{МАТЕРИАЛ D: ПЕРЕПИСКА Сценарии}

[Для всех версий]

Уильям и Джейн являются парой уже несколько месяцев. Недавно Джейн стало казаться, что Уильям снова пишет сообщения своей бывшей девушке Саре. Фактически Уильям отправил Саре сообщение на день рождения, и с тех пор они ежедневно переписываются. Однако Уильям не хочет, чтобы Джейн знала, что он регулярно пишет Саре. Поэтому, когда Джейн спрашивает: «Ты недавно снова писал Саре?»- Уильям...

$\begin{array}{llll}\text { [Предположение]... } & {[\mathrm{GCI}] \ldots \text {.отвечает: }} & {[\mathrm{PCI}] \ldots \text { отвечает: }} & \text { [Действие]...достает } \\ \text { отвечает: «Ты так } & \text { «Эо был ее } & \text { «На мой взгляд, } & \begin{array}{l}\text { свой телефон, быстро } \\ \text { спрашиваешь, как }\end{array} \\ \text { будто я писал ей } & \text { я написал ей один } & \text { нет ничего плохого } & \text { и незаметно удаляет } \\ \text { более того одного } & \text { раз». } & \text { отправить бывшей } & \text { все сообщения из } \\ \text { раза на день } & & \text { одно небольшое } & \text { чата, за исключением } \\ \text { рождения». } & \text { сообение на день } & \text { того первого своего } \\ & \text { рождения» } & \text { сообщения, которое } \\ & & \text { он послал Саре на } \\ & & \text { день рождения, и } \\ & & \text { показывает историю } \\ & & \text { переписки Джейн. }\end{array}$

[Для всех версий]

Джейн поверила, что Уильям написал Саре только один раз на ее день рождения.

\section{Зависимые переменные}

\begin{tabular}{|c|c|c|c|}
\hline [Предположение] & {$[\mathrm{GCI}]$} & {$[\mathrm{PCI}]$} & [Действие] \\
\hline $\begin{array}{l}\text { Пожалуйста, ответьте } \\
\text { на следующие } \\
\text { вопросы, } \\
\text { относящиеся } \\
\text { к заявлению } \\
\text { Уильяма «Ты так } \\
\text { спрашиваешь, } \\
\text { как будто я писал } \\
\text { ей более того } \\
\text { одного раза на } \\
\text { день рождения» в } \\
\text { качестве ответа на } \\
\text { вопрос Джейн «Ты } \\
\text { недавно снова писал } \\
\text { Саре?» }\end{array}$ & $\begin{array}{l}\text { Пожалуйста, ответьте } \\
\text { на следующие } \\
\text { вопросы, } \\
\text { относящиеся к } \\
\text { заявлению Уильяма } \\
\text { «Это был ее день } \\
\text { рождения, и я } \\
\text { написал ей один раз» } \\
\text { в качестве ответа на } \\
\text { вопрос Джейн «Ты } \\
\text { недавно снова писал } \\
\text { Саре?» }\end{array}$ & $\begin{array}{l}\text { Пожалуйста, ответьте } \\
\text { на следующие } \\
\text { вопросы, } \\
\text { относящиеся к } \\
\text { заявлению Уильяма } \\
\text { «На мой взгляд, } \\
\text { нет ничего плохого } \\
\text { в том, чтобы } \\
\text { отправить бывшей } \\
\text { одно небольшое } \\
\text { сообщение на } \\
\text { день рождения» в } \\
\text { качестве ответа на } \\
\text { вопрос Джейн «Ты } \\
\text { недавно снова писал } \\
\text { Саре?» }\end{array}$ & $\begin{array}{l}\text { Пожалуйста, ответьте } \\
\text { на следующие } \\
\text { вопросы, относящиеся } \\
\text { к тому, что Уильям } \\
\text { показывает Джейн } \\
\text { историю чата после } \\
\text { произведенных } \\
\text { манипуляций с ней в } \\
\text { качестве реакции на } \\
\text { вопрос Джейн «Ты } \\
\text { недавно снова писал } \\
\text { Саре?» }\end{array}$ \\
\hline \multicolumn{4}{|c|}{$\begin{array}{l}\text { [Для всех версий] } \\
(\text { Нравственность) Как бы Вы оценили поведение Уильяма с моральной точки зрения? } \\
\text { [очень плохо (1) - (7) очень хорошо] }\end{array}$} \\
\hline
\end{tabular}




\title{
Appendix 2: English Version of All Vignettes Tested in the Study
}

\section{CONTENT A: LOTTERY}

Scenarios

\begin{abstract}
[All versions]
Last year Emma's mother passed away, leaving her a large amount of money behind. With that money, Emma bought herself a nice and big house. Surprisingly, shortly after, Emma also won the lottery, receiving another large amount of money. Today Emma is working in her new house's front yard when her acquaintance Clara, who Emma had not talked to in a while, incidentally walks by on the footway. Emma does not want Clara to know that she bought her house with money she inherited from her mother. That is why, when Clara starts a conversation and asks, 'How did you afford a place like this?' Emma...

\begin{tabular}{|c|c|c|c|}
\hline $\begin{array}{l}\text { [Presupposition] } \\
\text {... answers, 'I admit that } \\
\text { I bought this house } \\
\text { with money I won in } \\
\text { the lottery last year!' }\end{array}$ & $\begin{array}{l}\text { [GCI] } \\
\text {...answers, 'Well, last } \\
\text { year I won the lot- } \\
\text { tery and bought this } \\
\text { place!' }\end{array}$ & $\begin{array}{l}\text { [PCI }] \\
\text {...answers, 'Well, win- } \\
\text { ning the lottery allows } \\
\text { people to buy the } \\
\text { houses they've always } \\
\text { dreamt of!' }\end{array}$ & $\begin{array}{l}\text { [Action] } \\
\text {..takes out her smart- } \\
\text { phone and shows Clara } \\
\text { a photograph of herself } \\
\text { posing with a giant } \\
\text { lottery cheque in front } \\
\text { of her newly purchased } \\
\text { house. }\end{array}$ \\
\hline
\end{tabular}
\end{abstract}

[All versions]

Clara comes to believe that Emma won the lottery and that she used the money from the lottery win to buy her new house.

\section{Dependent variables}

\begin{tabular}{|c|c|c|c|}
\hline [Presupposition] & {$[\mathrm{GCI}]$} & {$[\mathrm{PCI}]$} & [Action] \\
\hline $\begin{array}{l}\text { Please answer the } \\
\text { following questions } \\
\text { regarding Emma's } \\
\text { statement, 'I admit } \\
\text { that I bought this } \\
\text { house with money I } \\
\text { won in the lottery last } \\
\text { year!' as a response } \\
\text { to Clara's question, } \\
\text { 'How did you afford a } \\
\text { place like this?' }\end{array}$ & $\begin{array}{l}\text { Please answer the } \\
\text { following questions } \\
\text { regarding Emma's } \\
\text { statement, 'Well, last } \\
\text { year I won the lot- } \\
\text { tery and bought this } \\
\text { place!' as a response } \\
\text { to Clara's question, } \\
\text { 'How did you afford a } \\
\text { place like this?' }\end{array}$ & $\begin{array}{l}\text { Please answer the } \\
\text { following questions } \\
\text { regarding Emma's } \\
\text { statement, 'Well, } \\
\text { winning the lottery } \\
\text { allows people to buy } \\
\text { the houses they've } \\
\text { always dreamt of!' as } \\
\text { a response to Clara's } \\
\text { question, 'How did } \\
\text { you afford a place like } \\
\text { this?' }\end{array}$ & $\begin{array}{l}\text { Please answer the follow- } \\
\text { ing questions in regard } \\
\text { to Emma showing } \\
\text { Clara the photograph of } \\
\text { herself posing with the } \\
\text { lottery cheque in front } \\
\text { of her newly purchased } \\
\text { house as a response to } \\
\text { Clara's question, 'How } \\
\text { did you afford a place } \\
\text { like this?' }\end{array}$ \\
\hline
\end{tabular}

[All versions]

(Morality) How would you morally evaluate Emma's behaviour?

[very bad (1) - (7) very good]

To what extent do you disagree or agree with the following claims:

(Misleading) Emma misled Clara when responding to her question.

[completely disagree (1) - (7) completely agree]

(Lie) Emma lied to Clara when responding to her question.

[completely disagree (1) - (7) completely agree]

(Culpability) Emma committed a criminal offence when responding to Clara's question.

[completely disagree (1) - (7) completely agree] 


\section{CONTENT B: POLICE}

Scenarios

\section{[All versions]}

Peter, John and Carl are students training to become police officers at a police academy. Today, they had their final examinations. Unfortunately, all three of them failed the examinations. On their way out of the examination centre they run into their fellow trainee Sean. The three friends do not want Sean to know that they all failed the examinations. That is why, when Sean asks, 'So, did all of you guys fail the test today?' Peter...

[Presupposition] [GCI] [PCI]

[case excluded] ...answers, 'Well, some of ...answers, 'People you us failed the test.' dislike are not automatically losers.'

[All versions]

Sean comes to believe that not all of the three failed the examinations.

Dependent variables

$\begin{array}{lll}\text { [Presupposition] } & {[\mathrm{GCI}]} & {[\mathrm{PCI}]} \\ \text { [case excluded] } & \begin{array}{l}\text { Please answer the follow- } \\ \text { ing questions regarding }\end{array} & \begin{array}{l}\text { Please answer the follow- } \\ \text { ing questions regard- }\end{array} \\ & \begin{array}{l}\text { Peter's statement, 'Well, } \\ \text { some of us failed the }\end{array} & \begin{array}{l}\text { ing Peter's statement, } \\ \text { 'People you dislike }\end{array} \\ \text { test.' as a response to } & \text { are not automatically } \\ \text { Sean's question, 'So, did } & \text { losers.' as a response to } \\ \text { all of you guys fail the } & \text { Sean's question, 'So, did } \\ \text { test today?' } & \begin{array}{l}\text { all of you guys fail the } \\ \text { test today?' }\end{array}\end{array}$

[Action]

...grabs into his pocket, pulls out a police badge, which he wrongfully did not return upon his failure in the examinations, and shows it to Sean.

[All versions]

(Morality) How would you morally evaluate Peter's behaviour?

[very bad (1) - (7) very good]

To what extent do you disagree or agree with the following claims:

(Misleading) Peter misled Sean when responding to his question.

[completely disagree (1) - (7) completely agree]

( ie) Peter lied to Sean when responding to his question.

[completely disagree (1) - (7) completely agree]

(Culpability) Peter committed a criminal offence when responding to Sean's question.

[completely disagree (1) - (7) completely agree]

\section{CONTENT C: MARRIAGE}

\section{Scenarios}

\footnotetext{
[All versions]

At an alumni reunion, Frank meets his old classmate Harry. They start to talk about their relationships back in college and about the families they have now. In fact, Frank broke up with Jenny, who was his girlfriend in college, just a few years after they graduated. Last year, he then got married to another woman named Josephine, and he knows that his ex-girlfriend Jenny got married to another man last year as well. However, Frank does not want Harry to know that it did not work out for him and Jenny. That is why, when Harry asks, 'So, how did things turn out with you and Jenny?' Frank...
} 


\begin{tabular}{|c|c|c|c|}
\hline $\begin{array}{l}\text { [Presupposition] } \\
\text {...answers, 'The wedding } \\
\text { of Jenny and me was } \\
\text { beautiful!' }\end{array}$ & $\begin{array}{l}{[\mathrm{GCI}]} \\
\text {...answers, 'Jenny and I } \\
\text { got married last year!' }\end{array}$ & $\begin{array}{l}{[\mathrm{PCI}]} \\
\text { [case excluded] }\end{array}$ & $\begin{array}{l}\text { [Action] } \\
\text {...smiles brightly, raises his } \\
\text { hand, and shows Harry } \\
\text { his wedding ring engraved } \\
\text { with the letter ' } \mathrm{J} \text { ' on it. }\end{array}$ \\
\hline
\end{tabular}

[All versions]

Harry comes to believe that Frank got married to Jenny.

\title{
Dependent variables
}

\begin{tabular}{|c|c|c|c|}
\hline [Presupposition] & {$[\mathrm{GCI}]$} & {$[\mathrm{PCI}]$} & [Action] \\
\hline $\begin{array}{l}\text { Please answer the follow- } \\
\text { ing questions regarding } \\
\text { Frank's statement, 'The } \\
\text { wedding of Jenny and } \\
\text { me was beautiful!' as } \\
\text { a response to Harry's } \\
\text { question, 'So, how did } \\
\text { things turn out with you } \\
\text { and Jenny?' }\end{array}$ & $\begin{array}{l}\text { Please answer the follow- } \\
\text { ing questions regard- } \\
\text { ing Frank's statement, } \\
\text { 'Jenny and I got married } \\
\text { last year!' as a response } \\
\text { to Harry's question, 'So, } \\
\text { how did things turn out } \\
\text { with you and Jenny?' }\end{array}$ & [case excluded] & $\begin{array}{l}\text { Please answer the following } \\
\text { questions in regard to } \\
\text { Frank showing Harry his } \\
\text { wedding ring engraved } \\
\text { with the letter 'J' on it } \\
\text { as a response to Harry's } \\
\text { question, 'So, how did } \\
\text { things turn out with you } \\
\text { and Jenny?' }\end{array}$ \\
\hline
\end{tabular}

[All versions]

(Morality) How would you morally evaluate Frank's behaviour?

[very bad (1) - (7) very good]

To what extent do you disagree or agree with the following claims:

(Misleading) Frank misled Harry when responding to his question.

[completely disagree (1) - (7) completely agree]

( Lie) Frank lied to Harry when responding to his question.

[completely disagree (1) - (7) completely agree]

(Culpability) Frank committed a criminal offence when responding to Harry's question.

[completely disagree (1) - (7) completely agree]

\section{CONTENT D: TEXTING}

\section{Scenarios}

\begin{abstract}
[All versions]
William and Jane have been a couple for a few months now. Recently, Jane has been under the impression that William is texting his ex-girlfriend Sarah again. In fact, William texted Sarah for her birthday and since then they have been exchanging texts daily. However, William does not want Jane to know that he has been texting Sarah on a regular basis. That is why, when Jane asks, 'Have you recently been texting Sarah again?' William...

\begin{tabular}{|c|c|c|c|}
\hline [Presupposition] & {$[\mathrm{GCI}]$} & {$[\mathrm{PCI}]$} & [Action] \\
\hline $\begin{array}{l}\text {... answers, 'You act } \\
\text { like I texted her more } \\
\text { than that one time for } \\
\text { her birthday.' }\end{array}$ & $\begin{array}{l}\text {...answers, 'It was her } \\
\text { birthday, and so I } \\
\text { texted her once.' }\end{array}$ & $\begin{array}{l}\text {...answers, 'In my } \\
\text { opinion, it's not } \\
\text { wrong to send your ex } \\
\text { one tiny text for their } \\
\text { birthday.' }\end{array}$ & $\begin{array}{l}\text {...grabs his phone, } \\
\text { quickly and secretly } \\
\text { deletes all messages } \\
\text { from his and Sarah's } \\
\text { chat history except for } \\
\text { the first text he sent } \\
\text { Sarah for her birthday, } \\
\text { and shows the chat his- } \\
\text { tory to Jane. }\end{array}$ \\
\hline
\end{tabular}
\end{abstract}

[All versions]

Jane comes to believe that William recently texted Sarah only once for her birthday. 


\section{Dependent variables}

\begin{tabular}{|c|c|c|c|}
\hline [Presupposition] & {$[\mathrm{GCI}]$} & [PCI $]$ & [Action] \\
\hline $\begin{array}{l}\text { Please answer the } \\
\text { following questions } \\
\text { regarding William's } \\
\text { statement, 'You act } \\
\text { like I texted her more } \\
\text { than that one time } \\
\text { for her birthday.' as } \\
\text { a response to Jane's } \\
\text { question, 'Have you } \\
\text { recently been texting } \\
\text { Sarah again?' }\end{array}$ & $\begin{array}{l}\text { Please answer the } \\
\text { following questions } \\
\text { regarding William's } \\
\text { statement, 'It was } \\
\text { her birthday, and so } \\
\text { I texted her once.' as } \\
\text { a response to Jane's } \\
\text { question, 'Have you } \\
\text { recently been texting } \\
\text { Sarah again?' }\end{array}$ & $\begin{array}{l}\text { Please answer the } \\
\text { following questions } \\
\text { regarding William's } \\
\text { statement, 'In my } \\
\text { opinion, it's not } \\
\text { wrong to send your } \\
\text { ex one tiny text for } \\
\text { their birthday.' as a } \\
\text { response to Jane's } \\
\text { question, 'Have you } \\
\text { recently been texting } \\
\text { Sarah again?' }\end{array}$ & $\begin{array}{l}\text { Please answer the follow- } \\
\text { ing questions in regard } \\
\text { to William showing } \\
\text { Jane the manipulated } \\
\text { chat history as a } \\
\text { response to her ques- } \\
\text { tion, 'Have you recently } \\
\text { been texting Sarah } \\
\text { again?' }\end{array}$ \\
\hline
\end{tabular}

[All versions]

(Morality) How would you morally evaluate William's behaviour?

[very bad (1) - (7) very good]

To what extent do you disagree or agree with the following claims:

(Misleading) William misled Jane when responding to her question.

[completely disagree (1) - (7) completely agree]

(Lie) William lied to Jane when responding to her question.

[completely disagree (1) - (7) completely agree]

(Culpability) William committed a criminal offence when responding to Jane's question.

[completely disagree (1) - (7) completely agree]

Funding Open Access funding enabled and organized by Projekt DEAL.

Availability of Material, Data and Code All materials are available in the Appendix. Data and code are available at https://osf.io/x4pnc/.

\section{Declarations}

Conflict of interest The authors have no conflicts of interest to disclose.

Open Access This article is licensed under a Creative Commons Attribution 4.0 International License, which permits use, sharing, adaptation, distribution and reproduction in any medium or format, as long as you give appropriate credit to the original author(s) and the source, provide a link to the Creative Commons licence, and indicate if changes were made. The images or other third party material in this article are included in the article's Creative Commons licence, unless indicated otherwise in a credit line to the material. If material is not included in the article's Creative Commons licence and your intended use is not permitted by statutory regulation or exceeds the permitted use, you will need to obtain permission directly from the copyright holder. To view a copy of this licence, visit http://creativecommons.org/licen ses/by/4.0/.

\section{References}

Adha, A. 2020. Indonesians do not believe in lying: New results of replicating Coleman and Kay's study. Pro-Fil 21 (1): 11-23.

Adler, J.E. 1997. Lying, deceiving, or falsely implicating. The Journal of Philosophy 94 (9): 435-452. 
Antomo, M., S. Müller, K. Paul, M. Paluch, and M. Thalmann. 2018. When children aren't more logical than adults: An empirical investigation of lying by falsely implicating. Journal of Pragmatics 138: $135-148$.

Arico, A.J., and D. Fallis. 2013. Lies, damned lies, and statistics: An empirical investigation of the concept of lying. Philosophical Psychology 26 (6): 790-816.

Carson, T.L. 2006. The definition of lying. Noûs 40 (2): 284-306.

Carson, T.L. 2010. Lying and deception: Theory and practice. Oxford: Oxford University Press.

Chisholm, R.M., and T.D. Feehan. 1977. The intent to deceive. The Journal of Philosophy 74 (3): $143-159$.

Cole, S. 1996. Semantic prototypes and the pragmatics of Lie across cultures. The LACUS Forum 23: 475-483.

Coleman, L., and P. Kay. 1981. Prototype semantics: The English word lie. Language 57 (1): 26-44.

Davis, W. 2019. Implicature. In The Stanford encyclopedia of philosophy (Fall 2019 ed.), ed. E.N. Zalta. Retrieved from https://plato.stanford.edu/entries/implicature/.

Dynel, M. 2011. A web of deceit: A neo-Gricean view on types of verbal deception. International Review of Pragmatics 3 (2): 137-165.

Eichelberger, J. 2012. A semantic and pragmatic analysis of the Spanish word 'lie': Implications and applications for the second language learner [Doctoral dissertation, Baylor University]. Retrieved from https:// baylor-ir.tdl.org/handle/2104/8426.

Everett, J.A.C., C.J. Clark, P. Meindl, J.B. Luguri, B.D. Earp, J. Graham, P.H. Ditto, and A.F. Shariff. 2021. Political differences in free will belief are associated with differences in moralization. Journal of Personality and Social Psychology 120 (2): 461-483.

Fallis, D. 2009. What is lying? The Journal of Philosophy 106 (1): 29-56.

Grice, P. 1989. Studies in the way of words. Cambridge: Harvard University Press.

Hall, E.T., and W.F. Whyte. 1979. Intercultural communication. In Basic readings in communication theory, 2nd ed., ed. C.D. Mortensen. New York: Harper \& Row.

Hardin, K.J. 2010. The Spanish notion of lie: Revisiting Coleman and Kay. Journal of Pragmatics 42 (12): 3199-3213.

Henrich, J., S.J. Heine, and A. Norenzayan. 2010. The weirdest people in the world? Behavioral and Brain Sciences 33 (2-3): 61-83.

Horn, L.R. 2017. Almost et al.: Scalar adverbs revisited. In Contrastiveness in information structure, alternatives and scalar implicatures. Studies in natural language and linguistic theory, eds. Lee, C., F. Kiefer, and M. Krifka, Vol. 91, 283-304. Springer, Berlin.

Levinson, S.C. 2000. Presumptive meanings: The theory of generalized conversational implicature. Cambridge: MIT Press.

Mahon, J.E. 2016. The definition of lying and deception. In The Stanford encyclopedia of philosophy (Winter 2016 ed.), ed. E.N. Zalta. Retrieved from https://plato.stanford.edu/entries/lying-definition/.

Or, S., M. Ariel, and O. Peleg. 2017. The case of literally true propositions with false implicatures. In Deception and deceptive communication: Motivations, recognition techniques and behavioral control, ed. I. Chiluwa, 67-108. New York: Nova Science.

Palan, S., and C. Schitter. 2018. Prolific.ac—A subject pool for online experiments. Journal of Behavioral and Experimental Finance 17: 22-27.

Peng, K., and R.E. Nisbett. 1999. Culture, dialectics, and reasoning about contradiction. American Psychologist 54 (9): 741-754.

Reins, L.M., and A. Wiegmann. 2021. Is lying bound to commitment? Empirically investigating deceptive presuppositions, implicatures, and actions. Cognitive Science 45 (2): e12936.

Sakaba, H. 2020. The difference of Japanese Uso and English Lie from the perspective of speech acts. Osaka University Knowledge Archive 29: 35-55.

Saul, J.M. 2012. Lying, misleading, and what is said: An exploration in philosophy of language and in ethics. Oxford: Oxford University Press.

Seiter, J.S., J. Bruschke, and C. Bai. 2002. The acceptability of deception as a function of perceivers' culture, deceiver's intention, and deceiver-deceived relationship. Western Journal of Communication 66 (2): $158-180$.

Shatilova, L.M., V.V. Borisova, and O.A. Kasatkina. 2018. Representation of the linguistic and cultural concept "lie" in the French and Russian language picture of the world. Opción: Revista de Ciencias Humanas y Sociales 85: 257-276.

Sorensen, R. 2007. Bald-faced lies! Lying without the intent to deceive. Pacific Philosophical Quarterly 88 (2): 251-264. 
Sorensen, R. 2017. I—Lucifer's logic lesson: How to lie with arguments. Aristotelian Society Supplementary 91 (1): 105-126.

Spencer-Rodgers, J., M.J. Williams, and K. Peng. 2010. Cultural differences in expectations of change and tolerance for contradiction: A decade of empirical research. Personality and Social Psychology Review 14 (3): 296-312.

Stokke, A. 2013a. Lying and asserting. The Journal of Philosophy 110 (1): 33-60.

Stokke, A. 2013b. Lying, deceiving, and misleading. Philosophy Compass 8 (4): 348-359.

Stokke, A. 2018. Lying and insincerity. Oxford: Oxford University Press.

Thalmann, M., Y. Chen, S. Müller, M. Paluch, and M. Antomo. 2021. Against PCI-GCI uniformity. Evidence from deceptive language in German and Chinese. In Linguistische Berichte 267: 355-385.

Tower, R.K., C. Kelly, and A. Richards. 1997. Individualism, collectivism and reward allocation: A cross-cultural study in Russia and Britain. British Journal of Social Psychology 36 (3): 331-345.

Varnum, M., I. Grossmann, D. Katunar, R. Nisbett, and S. Kitayama. 2008. Holism in a European cultural context: Differences in cognitive style between Central and East Europeans and Westerners. Journal of Cognition and Culture 8 (3-4): 321-333.

Viebahn, E. 2020. Lying with Presuppositions. Noûs, 54: 731-751. https://doi.org/10.1111/nous.12282

Viebahn, E., A. Wiegmann, N. Engelmann, and P. Willemsen. In press. Can a question be a lie? An empirical investigation. Ergo.

Weissman, B., and M. Terkourafi. 2019. Are false implicatures lies? An Empirical Investigation. Mind \& Language 34 (2): 221-246.

Wiegmann, A., and J. Meibauer. 2019. The folk concept of lying. Philosophy Compass 14 (8): e12620.

Wiegmann, A., and P. Willemsen. 2017. How the truth can make a great lie: An empirical investigation of lying by falsely implicating. In Proceedings of the 39th Annual Conference of the Cognitive Science Society, eds. G. Gunzelmann, A. Howes, T. Tenbrink, and E.J. Davelaar, 3516-3621. Cognitive Science Society.

Wierzbicka, A. 2002. Russian cultural scripts: The theory of cultural scripts and its applications. Ethos 30 (4): 401-432.

Yoshimura, K. 1995. Ninchi Imiron no Houhou [The way of cognitive semantics]. Kyoto: Jinbun Shoin.

Stokke, A. (2017). II-Conventional implicature, presupposition, and lying. Aristotelian Society Supplementary, 91, 127-147. https://doi.org/10.1093/arisup/akx004.

Publisher's Note Springer Nature remains neutral with regard to jurisdictional claims in published maps and institutional affiliations. 